\title{
A Retrospective Qualitative Study on Current Diabetic Foot Ulcer Management and Discussion on Extended Role of Clinical Pharmacist
}

\author{
A. Porselvi, M. S. Uma Shankar, K. S. Lakshmi, V. Sankar
}

\begin{abstract}
Diabetic foot ulcers (DFU) are chronic complications due to poor diabetic control. Diabetic foot ulcers can lead to lifelong disability and substantially diminish the quality of life. The aim of this study was to carry out a thorough evaluation of diabetic foot ulcer management, compare current scenario of DFUs care with the International guidelines and to identify the extended roles of clinical pharmacist to improve the conditions of diabetic patient with foot ulcers.

It is a retrospective qualitative study carried out in two tertiary care hospitals of Tamil Nadu state. The patients were selected based on inclusion and exclusion criteria admitted in the hospitals with diabetic foot ulcers. The patient's sociodemographic and clinical characteristics tools from the patient medication records (PMR) were collected and taken into considerations for the study.

The study revealed that diabetic foot ulcer was more prevalent among male patients with type 2 diabetes since 11 to $25 \mathrm{yrs}$ belongs to the age group between 51-60 years. It was found that $60.5 \%$ of the patients having at least one co-morbid condition
\end{abstract}

and $90.6 \%$ of patients possess one or more risk factors to develop diabetic foot ulcers. Glycated hemoglobin $\left(\mathrm{HbA}_{1 \mathrm{c}}\right)$ test were done only by $54.7 \%$ of the patients, which showed that it was not insisted as an important identification tool for diabetic foot ulcer. The PMR revealed numerous antibiotics switch-over for the wound treatment as well.

From the study it was concluded that an immediate requirement and thorough evaluation of enhanced foot care management, patient centered care and diabetic foot surveillance etc is needed for diabetic foot ulcer management. A comparative current scenario of DFUs care with the International guidelines and its adaptation and modifications according to our need is to be emphasized. Amalgamation of clinical pharmacy services with the multidisciplinary diabetic foot care team services is to be made. The clinical pharmacist's intervention is to be put forward to improve the conditions of diabetic patient with foot ulcers to decrease the alarming incidences in Indian hospital settings.

Key Words: Diabetes, diabetic foot ulcer, wounds, guidelines, clinical pharmacy intervention
A. Porselvi, M. S. Uma Shankar, K. S. Lakshmi

SRM College of Pharmacy, SRM University, Kattankulathur, India.

V. Sankar

PSG College of Pharmacy, Coimbatore, India.

Corresponding Author:

M. S. Uma Shankar

e-mail:umashankar.s@ktr.srmuniv.ac.in
Submitted / Gönderilme: 26.08.2016

Accepted / Kabul: 17.11.2016

Revised / Düzeltme: 14.11 .2016

\section{INTRODUCTION}

Diabetes is a group of heterogeneous disorders characterized by hyperglycemia and glucose intolerance due to insulin deficiency, impaired effectiveness of insulin action, or both [1]. About 15\%-25\% of diabetic patients will develop chronic ulcers of foot or lower extremity during their lifetime [2-4].The etiology of foot ulcers is multi-factorial [3,5] among which peripheral vascular disease, neuropathy and retinopathy are considered to be the most important causative factors [6]. Foot ulcers in diabetic patient are the major sufferings and cost-effective [7]. Diabetic foot ulcer patients use more in and outpatient health resources and 
this condition is one of the main factors for the hospital admission of diabetic patients [8].

In India incidence of foot ulcers vary by many socio-cultural practices which include barefoot walking, inadequate facilities for diabetic care, low levels of education and poor socio-economic conditions [9]. $\mathrm{HbA}_{1 \mathrm{C}}$ measurements are used to test metabolic control in diabetics at least three months, and to assess the risk for complications [10]. Diabetic foot ulcer (DFU) can lead to lifelong disability and may substantially diminish the quality of life in these patients and only two third of these ulcers are expected to heal [1114]. The median time taken for the healing of these ulcers is approximately 6 months; up to $28 \%$ may result in some form of amputation [15] and the amputee patient's life expectancy was found to be 4.32 years in a study [16].

If the treatment provided is inadequate that may result in therapeutic complications and unnecessary extension of healing times [17]. A variety of antibiotics ranging from narrow spectrum oral agents to broad spectrum parenteral agents are employed in treating diabetic foot infections. During the recent two decades study there are only a few investigations on antimicrobial therapy defined for the infections [18]. Studies on cost effectiveness of antimicrobials are very limited. The Infectious Society of India (IDSA) guideline recommends deep tissue culture study obtained by biopsy or curettage as study specimen and also suggest avoiding swab specimens, especially from inadequately debrided wounds, as they provide less accurate results.

Foot ulcers are susceptible to infection and poly-microbial infection which may spread rapidly, causing overwhelming tissue destruction. This process is the main reason for major amputation in neuropathic feet. Potential strategies to minimize the sequelae of foot complications includes early recognition of the 'at risk' foot; prompt use of preventative measures; and rapid and intensive treatment of foot complications in multidisciplinary foot care services [19-21]. Diabetic foot care guidelines considered to be one of the most cost-effective forms of health care expenditures provided that the guideline is goal-focused and properly implemented. International Diabetes Federation (IDF), Diabetes Atlas

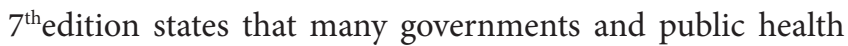
planners are still remain unaware of the current magnitude and more importantly the future potential increase of diabetes cases as well as its serious complication in their own countries. National Institute of Clinical Excellence (NICE) guideline insists patient centered care for foot ulcers with type 1 and type 2 diabetes patients, where treatment and care should be taken into account according to the individual needs and preferences. Diabetic foot ulcer management centers have documented reductions in amputation rates up to $50 \%$ after coordinating the multidisciplinary efforts and incorporation of evidence-based wound care managements [22-28].

\section{Aim}

The aim of the study was to carry out a thorough evaluation of current DFU management, compare with international guidelines and to identify clearly the extended roles of the Clinical Pharmacist in the management and prevention of DFU.

\section{Objective}

- To identify current diabetic foot ulcer treatment and management modalities.

- To identify and compare essential domains in the DFU management and prevention.

- To identify the extended responsibilities of clinical and community pharmacy services.

- To emphasize and discuss on the implementation of an effective prevention programme and standard practice.

\section{Research design}

\section{Sample Setting}

The retrospective qualitative study based on grounded theory method was conducted in two different tertiary care hospitals in Coimbatore and Chennai located in South India. The study was carried out at two different time periods for a total of 10 months. All procedures performed in the study were in accordance with the ethical standards of the institution and the study required no any formal consent.

\section{Patient selection criteria}

The two different study periods were taken, from March 2013 to September 2013 and from December 2015 to February 2016 respectively. and no any patients were repeated in the study. Type1 or type 2 diabetes mellitus patients of any age group, diagnosed with diabetic foot ulcers under medication with the prescribed antibiotics and who fulfilled the inclusion criteria, a total of 97 patients were recruited randomly from 
inpatient wards from various departments of the tertiary care hospital. The highest numbers of diabetic foot ulcer patients were found in both male and female surgical wards. 86 patients were included in the study and remaining 11 patients were excluded from the study based on the inclusion-exclusion criteria. Exclusion criteria involve nondiabetic patients, patients with cellulitic foot ulcer, diabetic patients with varicosities, patient with vasculitic ulcerations and lower extremity rashes.

\section{Study design and methodology}

This study was carried out in three phases.

Phase-I comprises review of Diabetes and Diabetic foot Ulcer Guidelines of National Institute of Clinical Excellence, UK; National Diabetes Education Program, USA and Infectious Diseases Society of America. A new patient documentation form was developed based on the requirement of these guidelines for the diabetic foot ulcer management.

Phase-II includes recruiting of patients under inclusionexclusion criteria based on the standard ethics. Patient documentation form (PDF) was designed, developed and tailored according to the study requirement based on the "Diabetes Care Program of Nova Scotia, Canada; National Diabetes Education Program, USA; Association of Wound Care and The National Institute of Clinical Excellence, UK" guidelines. Socio-demographic details of the selected patients were entered in the developed patient documentation form (PDF).

Phase-III involves the collection of patient's variable factors like age, gender, diabetes type, duration of diabetic illness, risk factors, co-morbidities, culture test, antibiotics, length of stay, $\mathrm{HbA}_{1 \mathrm{c}}$ level, fasting blood sugar, random blood sugar value etc taken into consideration for the study were grouped, analyzed and discussed.

\section{Data Assessment and Management}

The details obtained were brought under the domains like "Structured Foot Surveillance, Assessment of Risk Factors, Treatment and Management for ulcer and Prevention Measures" which were indicated by NICE guidelines as the requirements for diabetic foot ulcer management in hospital settings. For a descriptive analysis, basic statistical characters like mean, percentage and \pm standard deviation were used.

\section{Results}

The study analyzed the selected 86 patients from PMR based on the classifications of gender, age, type and duration of diabetes, co-morbid conditions, risk factors, culture test, and $\mathrm{HbA}_{1 \mathrm{c}}$ test and length of stay in hospital. The results of the basic socio-demographic and clinical characteristics of the patients were summarised in Table 1.

Table 1: Basic socio-demographic and clinical characteristics of the patients

\begin{tabular}{|c|c|c|c|}
\hline Character & tics & $\mathrm{N}=86$ & $\%$ \\
\hline \multirow{3}{*}{ Sex } & Men & 59 & 68.6 \\
\hline & & & \\
\hline & Women & 27 & 31.4 \\
\hline \multirow{2}{*}{ DM Type } & Type 1 DM & 3 & 3.5 \\
\hline & Type 2 DM & 83 & 96.5 \\
\hline \multirow{2}{*}{ Co-morbid conditions } & Patients with & 52 & 60.5 \\
\hline & Patients without* & 34 & 39.5 \\
\hline \multirow{3}{*}{ Risk factors } & Patients with & 78 & 90.6 \\
\hline & Patients with out & 4 & 4.7 \\
\hline & Information N/A & 4 & 4.7 \\
\hline \multirow{2}{*}{$\begin{array}{l}\text { Glycated Haemoglobin } \\
\qquad \mathrm{HbA}_{1 \mathrm{c}} \text { Test }\end{array}$} & Performed & 47 & 54.7 \\
\hline & Not performed & 39 & 45.3 \\
\hline \multirow{2}{*}{ Culture test } & Performed & 51 & 59.3 \\
\hline & Not performed & 35 & 40.7 \\
\hline \multirow{2}{*}{ Isolated organism $(\mathrm{N}=51)$} & Single & 20 & 39.2 \\
\hline & Mixed & 31 & 60.8 \\
\hline
\end{tabular}

From the total sample size of 86 patients, men were around $68.6 \%$ and $31.4 \%$ were women among the admitted patients. Most of the patients (96.5\%) admitted were type2 diabetes. The patients around $60.5 \%$ were recorded to be having at least one co-morbid condition like high blood pressure, dyslipidemia and renal failure. The glycated haemoglobin test was performed with only 47 patients (54.7\%). Culture test was done in 51 patients (59.3\%) and among them single organism was isolated in 20 patients and mixed organisms were isolated in 31 patients. From the blood sample analysis for the selected patients, it was found that the $\mathrm{HbA}_{1 \mathrm{c}}$ test 
was done only of the patients. Among the study population about $90.6 \%$ were identified to have one or more risk factors Table 2, were likely to develop DFU. Poor glycemic control $(44.18 \%)$ and diabetes for more than 10 years (30.2\%) reported possesses the high risks of diabetic foot ulcers followed by history of previous amputation (25.6\%), diabetic nephropathy (16.2\%) and past foot ulcer history (11.6\%).

Table 2: Risk factors

\begin{tabular}{cccc}
\hline S. No & List of Risk Factors $^{\$}$ & $\begin{array}{c}\text { No of } \\
\text { Patients }^{*}\end{array}$ & $\begin{array}{c}\text { \% } \\
\text { N=86 }\end{array}$ \\
\hline 1 & Diabetes for $\geq 10$ years & 38 & 44.18 \\
2 & Past Foot Ulcer History & 26 & 30.23 \\
3 & Previous Amputation & 22 & 25.58 \\
5 & Peripheral Neuropathy & 14 & 16.27 \\
6 & Peripheral Vascular Disease & 10 & 11.62 \\
7 & Poor Glycemic Control & 51 & 59.30 \\
8 & Visual Impairment & 19 & 22.09 \\
9 & Diabetic Nephropathy & 26 & 30.23 \\
\hline
\end{tabular}

$\$$-On the basis of patient record

*-Patient's every single risk factor is recorded under each category

Clinical characteristics of patients correlating with the development of DFU like age wise distribution, duration of diabetes and the length of stay in the hospital was categorized and summarized in Table 3. DFU incidences based on the age wise analysis revealed that the age between 51-60 years (39.5\% of mean age 55.68) were found to be the more vulnerable to develop DFU followed by $61-70$ years (31.4\%) and 41-50 years (16.3\%). There were patients having DFU each, one case from below 30 years and one above 80 years. The patients around $46.16 \%$ who developed DFU were found to have diabetes, duration 11-25 years. Unfortunately information on duration of diabetics were missing for 21 (24.4\%) of the patients. Patients stay in the hospital was less than a week to a month and a half. Information on frequency of admissions of the same patients or who had visited other clinics was lacking. Patients stayed less than a week were more in numbers and their average stay was found to be 5.03 days.
Table 3: Clinical characteristics of patient with diabetic ulceration

\begin{tabular}{|c|c|c|c|c|}
\hline Characteristics & & $\mathrm{N}=86$ & $\%$ & Mean \pm SD \\
\hline \multirow{7}{*}{ Age wise distribution (yrs) } & $\leq 30$ & 1 & 1.16 & $\mathrm{NA}^{* *}$ \\
\hline & $31-40$ & 3 & 3.49 & $35.33 \pm 2.52$ \\
\hline & $41-50$ & 14 & 16.28 & $44.3 \pm 3.36$ \\
\hline & $51-60$ & 34 & 39.54 & $55.68 \pm 2.86$ \\
\hline & $61-70$ & 27 & 31.39 & $65.33 \pm 2.91$ \\
\hline & $71-80$ & 6 & 6.98 & $72.83 \pm 2.48$ \\
\hline & $81-90$ & 1 & 1.16 & NA \\
\hline \multirow{4}{*}{$\begin{array}{l}\text { Duration of Diabetes in yrs } \\
\qquad(\mathrm{n}=65)\end{array}$} & $\leq 1$ & 6 & 9.23 & $09 \pm 2.37^{*}$ \\
\hline & $2-5$ & 15 & 23.07 & $03.53 \pm 1.06$ \\
\hline & $6-10$ & 14 & 21.54 & $08.29 \pm 1.38$ \\
\hline & $11-25$ & 30 & 46.16 & $16.87 \pm 5.07$ \\
\hline \multirow{6}{*}{ Length of stay in days } & $\leq 7$ & 33 & 38.37 & $05.03 \pm 1.53$ \\
\hline & $8-14$ & 29 & 33.73 & $11.14 \pm 1.94$ \\
\hline & $15-21$ & 13 & 15.12 & $17.54 \pm 1.85$ \\
\hline & $22-28$ & 7 & 8.14 & $25.00 \pm 2.16$ \\
\hline & $29-35$ & 2 & 2.32 & $32.50 \pm 2.12$ \\
\hline & $36-42$ & 2 & 2.32 & $39.50 \pm 2.12$ \\
\hline
\end{tabular}

${ }^{*}$ value in month

${ }^{* *}$ NA-not applicable

\section{DISCUSSION}

Risk of poorly controlled glycaemia had a high impact on the development of diabetic foot ulcers. Peripheral vascular disease, diabetic retinopathy and nicotine/cigarette smoking were also considerably found to be important while assessing the risk factors which can worsen the condition of diabetic foot ulcers. Previous studies had proved that there was a positive correlation between the treatment failures and the presence of risk factors. The available data for understanding the management of DFU and complications in the local hospital settings required to be improvised. The patient's past medical history records can be modified with more relevant information. Treating the DFU patients under standardized practices would be more appropriate adopting the International DFU care to bring positive outcomes. 
Comparison of the important domains for the effective management and prevention of DFU had been shown in Table 4. HbA1c was not done to the whole patients; reason being the cost factor, can be made cheaper and lack of guidelines insisting $\mathrm{HbA}_{1 \mathrm{C}}$ is a mandatory diagnostic test for DFU was observed. Co-morbidities seen in DFU patients can be advised that it would worsen their health and it was found that an increased number of medicines were consumed by the patient.

Table 4: Study report on comparison of domains

\begin{tabular}{cccc}
\hline Domain/ Areas & $\begin{array}{c}\text { International } \\
\text { Guideline }\end{array}$ & Current care & $\begin{array}{c}\text { Possibility of } \\
\text { Implementation }\end{array}$ \\
\hline Guideline & $\sqrt{ }$ & $\mathrm{X}$ & Yes \\
Structured Education & $\sqrt{ }$ & $\mathrm{X}$ & Yes \\
Care planning & $\sqrt{ }$ & $\begin{array}{c}\text { No specific } \\
\text { plan }\end{array}$ & Yes \\
$\begin{array}{c}\text { Patient centred care } \\
\begin{array}{c}\text { Annual structured } \\
\text { foot surveillance }\end{array}\end{array}$ & $\sqrt{ }$ & $\mathrm{X}$ & Yes \\
$\begin{array}{c}\text { Referral and } \\
\text { management }\end{array}$ & $\sqrt{ }$ & $\mathrm{X}$ & Yes \\
$\begin{array}{c}\text { Multi disciplinary } \\
\text { diabetic foot care } \\
\text { Team }\end{array}$ & $\sqrt{ }$ & $\mathrm{X}$ & Yes \\
$\begin{array}{c}\text { Enhanced Foot Care } \\
\text { Education }\end{array}$ & $\sqrt{ }$ & $\mathrm{X}$ & Yes \\
\hline
\end{tabular}

* listed by the NICE guidelines

IDSA insists on deep tissue culture instead of swab or pus culture in order to obtain the accurate existence of microorganism. Though the list of isolated organisms was prepared on culture test yet the concordance with deep tissue culture and swab or pus culture must be ascertained. Treating DFU patients with the appropriate antibiotic regimen is crucial for the successful outcome and also to prevent antibiotic resistance which can ultimately reduce antibiotics switch-over events. IDSA has drawn guidelines for appropriate antibiotic regimen for the prophylaxis and treatment for classified DFU patients. Awareness, screening and surveillance programs can be organized at the hospitals centres, which could bring positive outcome in the society especially in India, where the diabetic population is expected to increase. Clinical Pharmacist intervention can be incorporated in rational use of antibiotics, risk assessment, antibiotic policy framing, organising awareness and preventive programs and other roles etc. which are listed below.

\section{Roles of Clinical Pharmacist postulated in the management of diabetic foot ulcer care}

D Develop, evaluate and document pharmaceutical care practices in DFU.

Collaborate with other health care professionals to develop treatment guidelines for DFU.

Educate all health professionals who participate in pharmaceutical care.

$>$ Participate in health screening for diabetes, and DFU ( $\mathrm{HbA}_{1 \mathrm{c}}$, FBS, PPBS, etc.).

$>$ Conducting health promotion and education programs for smoking cessation, obesity control, DFU self-practice; DFU preventive measures DFU awareness camp etc.

Educate and collaborate community pharmacist and their services in the prevention and

management of DFU.

Referral for management from counseling centers and community pharmacies.

Research in the field of pharmacotherapeutics; pharmacoepidemiology; pharmacy practice; health economics in diabetes and DFU.

To evaluate and document the results of research in order to improve all aspects of pharmaceutical care.

> Participate in the formulation of antibiotic policy and its regulations

$>$ Develop professional standards and audit procedures.

\section{Limitations of the study}

In this retrospective study some of the patient's medical and medications history entry were not made available PMR. The study was carried out with 86 diabetic patients among whom only 3 patients were having type 1 diabetes but more or equal numbers of type1 diabetes patients have to be recruited to confirm whether type 2 diabetes patients are also more vulnerable to develop DFU than type 1 diabetes.

\section{Conclusion}

An audit must be performed to identify high risk patients of diabetic foot ulcers and suitable preventive programmes 
can be introduced as per the guidelines. Annual surveillance for all diabetic foot ulcer patients must be conducted in the hospital by the foot care team (podiatrist) organised in the hospital for the management and prevention from prognosis which is highly emphasised by the guidelines. The clinical pharmacist should make an attempt to develop treatment guidelines in collaboration with other health care professionals. A unique system of classifying diabetic foot infections suggested by the guidelines must be followed in the hospital setup for the optimal use of antibiotics. In order to identify accurate organism deep tissue culture rather than pus and swab culture tests could be adopted by the hospitals. Antibiotic guidelines for treating DFU/DFI and recommendation for the same must be brought for both empirical and for the treatment of infections. Initiation of the multidisciplinary team and implementation of clinical pharmacy services in the areas of antibiotic policies and guidelines framing, surveillance for high and low risk patients, and in organising awareness and preventive programs are important for the positive treatment outcome among DFU patients. It can be concluded that it is necessary to classify the DFU patients under anyone of the standard classifying system to assess the risk factors based on which preventive strategies can be drawn.

Diyabetik Ayak Ülseri Tedavisi Üzerine Geçmişe Yönelik, Nicel Bir Çalışma ve Klinik Eczacının Artan Rolünün Tartışılması

\section{ÖZ}

Diyabetik ayak ülseri (DFU), diyabetin yetersiz kontrolü sonucunda gelişen kronik bir komplikasyondur. DFU, hastanın ayağını zorlukla kullanmasına neden olduğu için yaşam kalitesini de düşürmektedir. Bu çalışmanın amacı, DFU'nin kontrolü ve tedavisi konusunda kapsamlı bilgi vermek, uluslararası kılavuzlarda yer alan DFU tedavisi ve bakımı konusundaki verileri karşılaştırmak, ve ayaklarında ülser gelişmiş diyabetli hastaların durumlarının iyileştirilmesinde klinik eczacının gün geçtikçe artan rolünü ifade etmektir. Bu çalışma, Tamil Nadu'da bulunan ve üçüncü basamak sağlık hizmeti veren iki hastanede yürütülmüş olan geçmişe yönelik ve nitel bir çalışmadır.Çalışmaya katılacak hastalar, DFU nedeniyle hastaneye başvuran hastalar arasından dahil etme ve dişarıda bırakma kriterleri göz önünde bulundurularak seçilmiştir. Hastalara ait sosyodemografik ve klinik veriler hasta kayıtlarından (PMR) toplanmıştır.

$\mathrm{Bu}$ çalışma, DFU'nin, 11-25 yıldır tip-2 diyabet tanısı ile yaşayan 51-60 yaş aralığındaki erkek hastalarda karşılaştırılan

\section{Acknowledgment}

We would like to thank our respected Dean, SRM College of Pharmacy, for the acceptance of the study and MRO, SRM Hospital and PSG Hospital who helped for the data collection.

\begin{abstract}
Abbreviation
DM - Diabetes mellitus, DFU - Diabetic foot ulcer, WHO - World Health Organization, IDF - International Diabetes Federation, NICE - National Institute of Clinical Excellence, IDSA - International Diabetes Society of America, $\mathrm{HbA}_{1 \mathrm{c}}{ }^{-}$ glycated hemoglobin.
\end{abstract}

\section{Conflict of Interests}

The authors declare that they no conflict of interests.

\section{Ethical approval}

All procedures performed were in accordance with the ethical standards of the institution. For this type of study, formal consent is not required. diğer hasta gruplarına kıyasla daha fazla görüldüğünü ortaya çıkartmıştır. Hastalardan \%60.5'nin en az bir ko-morbid durum yaşadığı, hastaların \%90.6'sının ise DFU gelişimi açısından bir ya da daha fazla risk faktörü taşıdığı tespit edilmiştir. Glikozillenmiş hemoglobin $\left(\mathrm{HbA}_{1 \mathrm{c}}\right)$ testinin hastaların yalnızca \%54.7'sine uygulandiğı ve bu testin DFU'nin tanısı için üzerinde ısrarla durulan bir test olmadığı görülmüştür. Ayrıca, hasta kayıtlarından elde edinilen verilerde hastalara yara iyileşmesi için çok sayıda antibiyotik reçete edildiği saptanmıştır.

$\mathrm{Bu}$ çalışmada, DFU tedavisi ve bakımının acil bir gereklilik olduğu, DFU bakımı için hasta odaklı bir yaklaşım geliştirilmesi ve diyabetik ayak tarması yapılması gerektiği belirlenmiştir. Uluslararası kılavuzlarda bildirilen DFU tedavisi ve bakımının ülkemizdeki ihtiyaçlar göz önüne alınarak uyarlanması ve geliştirilmesi gereklidir.Klinik eczacılık hizmetleri ile çok disiplinli diyabetik ayak bakımı hizmetleri birleştirilmelidir. DFU'li hastaların yaşam kalitesinin arttırılması için klinik eczacıların sürece mutlaka katkıda bulunmasının Hindistan'da DFU nedeniyle hastanelere yapılan giderek artan sayıdaki başvuruyu önleyeceği düşünülmektedir.

Anahtar Kelimeler: Diyabet, diyabetik ayak ülseri (DFU), yaralar, kılavuzlar, klinik eczacılık hizmetleri. 


\section{References}

1. World Health Organization. Definition, Diagnosis and Classification of Diabetes Mellitus and its complications. Part 1: Diagnosis and Classification of Diabetes Mellitus. WHO/ NCD/NCS/99.2 ed. Geneva, World Health Organisation1999.

2. Palumbo PJ, Melton Lj. III. Peripheral vascular disease and diabetes. In: Diabetes in America. Harris MI, Hamman RF. US Government Printing Office, Washington DC. 1985; 1-21.

3. Reiber GE. The epidemiology of diabetic foot problems. Diabet Med 1996; 13:S6-S11.

4. Bartus CL, Margolis DJ. Reducing the incidence of foot ulceration and amputation in diabetes. Curr Diab Rep. 2004; 4: 413-8.

5. Bild DE, Selby JV, Sinnock P, Browner WS, Braveman P, Showstack JA. Lower- extremity amputation in people with Diabetes epidemiology and prevention. Diabetes Care 1989: 12: 24-31.

6. Edmonds ME. Progress in care of the diabetic foot. Lancet 1999: 354: 270-2.

7. Wild S, Roglic G, Green A, Sieree R King H. Global prevalence of diabetes: estimates for the year 2000 and projections for 2030. Diabetes Care 2004; 27:1047-53.

8. International Diabetes Federation. IDF Atlas, $4^{\text {th }}$ ed. Brusels, Belgium. 2009.

9. Vijay Snehalatha C, Terin M, Ramachandran A. Socio-cultural practices that may affect the development of the diabetic foot. IDF Bull 1997: 42; 10-2.

10. Alonso-Fernández M, Mancera-Romero J, Mediavilla-Bravo JJ, Comas-Samper JM, López-Simarro F, Pérez-Unanua MP, Iturralde-Iriso J; Work Group of Diabetes SEMERGEN (Sociedad Española de Médicos de Atención Primaria). Glycemic Control and Use of A1c In Primary Care Patients With Type 2 Diabetes Mellitus. Primary care Diabetes 2015; 9: 385-91.

11. Brod M. Quality of life issues in patients with diabetes and lower extremity ulcers: Patients and care givers. Qual Life Res 1998; 7: 365-72.

12. Popkin BM, Gordon- Larsen P. The nutrition transition: Worldwide obesity dynamics and their determinants. Int J Obes Relat Metab Disord. 2004; Suppl.3: S2-S9.

13. Unwin N. The diabetic foot in the developing world. Diabetes Metab Res Rev 2008; 24- Suppl I: S31-S33.

14. Jeffcoate WJ, Harding KG. Diabetic foot ulcers. Lancet 2003; 361: 1545-51.

15. Boulton AJ, Vleikyte L, Ragnarson- Tennvall G, Apelqvist J. The global burden of diabetic foot disease. Lancet 2005; 366 : 1719-24.
16. Abol Hassani F, Mohajeri Tehrani MR, Tabatabaei O, Larijani B. Burden of diabetes and its complications in Iran in the year 2000. Iran J Diabetes and Lipid Disord 2005; 5:35-48.

17. Reiber GE. The Epidemiology of diabetic foot problems. Diabet Med 1996; 13: S6-S11.

18. Al-wahbi AM. Impact of diabetic education program on lower limb amputation rate. Vasc Health Risk Manag 2010; 6: 92334 .

19. Bus SA, van Deursen RW, Armstrong DG, Lewis JE, Caravaggi CF, Cavanagh PR; International Working Group on the Diabetic Foot. ootwear and offloading interventions to prevent and heal foot ulcers and reduce plantar pressure in patients with diabetes: a systematic review. Diabetes Metab Res Rev 2016;32-Suppl 1:99-118.

20. Razgallah Khrouf M, Turki M, Louhaichi A, Guerfali M. Evaluation of the management of diabetic foot in Rabta National Teaching Hospital. Eur J Hosp Pharm 2013; 20.

21. Andersen AH, Fredriksen G, Major ALS, Sund JK. Evaluation of implementation of clinical pharmacy services in central Norway. Eur J Hosp Pharm 2013; 20: A183-A184.

22. Larsson J, Apelqvist J, Agardh CD, Stenstorm A. Decreasing incidence of major amputation in diabetic patients: a consequence of a multidisciplinary foot care team approach. Diabet Med 1995: 12; 770-6.

23. Edmonds ME, Blundell MP, Morris ME, Cotton LT, Watkins PJ. Improved survival of the diabetic foot: The role of a specialized foot clinic. Q J Med 1986; 60: 763-71.

24. Vedhara K, Miles JN, Wetherell MA, Dawe K, Searle A, Tallon D, Cullum N, DayA, Dayan C, Drake N, Price P, Tarlton J, Weinman J, Campbell R. Coping style and depression influence the healing of diabetic foot ulcers: observational and mechanistic evidence. Diabetologia 2010; 53: 1590-8.

25. Winkley K, Sallis H, Kariyawasam D, Leelarathna LH, Chalder T, Edmonds ME, Stahl D, Ismail K. Five-year follow-up of a cohort of people with their first diabetic foot ulcer: the persistent effect of depression on mortality. Diabetologia 2012; 55: 303-10.

26. Boulton AJ, Vileikyte L, Ragnarson-Tennvall G, Apelqvist J. The global burden of diabetic foot disease. Lancet. 2005; 366: 1719-24.

27. Toklu HZ, Akici A, Oktay Ş, Çali Ş, Sezen SF, Keyer-Uysal M. The pharmacy practice of community pharmacists in Turkey. Marmara Pharm J 2010; 14: 53-60.

28. Kalsi A, Singh S, Taneja N, Kukal S, Mani S. Current treatment for type 2 diabetes, their side effects and possible complementary treatments. Int J Pharm Pharm Sci 2015; 3: 13-8. 